\title{
Antibacterial and antifungal activity of toon tree bark's natural dye in aqueous medium
}

\author{
Deepa Tyagi and Pankaj Chhabra
}

Received: 27.09.2018; Revised: 06.05.2019; Accepted: 15.05.2019

See end of the paper for authors' affiliations Deepa Tyagi

Department of Home Science,

M.L. and J.N.K. Girls College,

Saharanpur (U.P.) India
ABSTRACT : Objectives: The present investigation was aimed to investigate the antibacterial and antifungal activity of natural dye from toon bark. Methods: Antibacterial and antifungal efficiency of natural dye were evaluated against gram positive bacteria Staphylococcus aurous, gram negative bacteria Escherichia coli and Chrysosporium fungus, Fusarium oxysporium fungus using agar well diffusion method. Result: The dye was found to have potent antibacterial activity against all the test bacteria at all the tested concentrations. Highest antibacterial activity against all the test bacteria was recorded with $400 \mathrm{mg} / \mathrm{ml}$ treatment. The dye was found to have potent antifungal activity against all the test bacteria at all the tested concentration. Higher antifungal activity against all the test fungal $400 \mathrm{mg} / \mathrm{ml}$ treatment. Conclusion: The study concluded that different selected barks can be a potential source of natural dye with remarkable antibacterial and antifungal potency which can applied in fabric for protective clothing.

KEY WORDS: Natural dye, Toon bark, Antibacterial activity, Antifungal activity

- HOW TO CITE THIS PAPER : Tyagi, Deepa and Chhabra, Pankaj (2019). Antibacterial and antifungal activity of toon tree bark's natural dye in aqueous medium. Asian J. Home Sci., 14 (1) : 169-174, DOI: 10.15740/HAS/AJHS/14.1/169-174. Copyright@ 2019: Hind Agri-Horticultural Society. 